\title{
TANGGUNG JAWAB DIREKSI ATAS TERJADINYA PAILIT PERSEROAN TERBATAS
}

\author{
Antonius Faebuadodo Gea \\ Prodi Magister Hukum, Fakultas Hukum-Universitas Mataram NTB \\ antoniusmih18@gmail.com \\ Hirsanuddin \\ Dosen Fakultas Hukum-Universitas Mataram NTB \\ hirsanuddinfh@unram.ac.id \\ Djumardin \\ Dosen Fakultas Hukum-Universitas Mataram NTB \\ drdjumadinfh@gmail.com
}

\begin{abstract}
This research was conducted to find out how the directors' accountability mechanism caused by an error or negligence caused the limited company to go bankrupt and how the legal consequences on the bankruptcy of a limited liability company. This type of research was classified as a normative legal research or also called doctrinal research, namely research that examined the law as a separate system that was separate from various other systems in society so as to provide a boundary between the legal system with other systems. The approach method used was the statutory approach; and Conceptual Approach. In principle, the Board of Directors was not personally responsible for acts committed for and on behalf of the company based on its authority. The scope of conduct that would be personally accounted for by the directors of the company was negligence because the directors did not fulfill the contents of the agreement and mistakes because the directors commit acts against the law. Bankruptcy of a Limited Liability Company was the bankruptcy of itself, not the bankruptcy of its management, even though the bankruptcy was due to the negligence of its management. So that management should not be held liable jointly for any losses due to negligence and could only be held accountable if the company's assets were not sufficient to cover losses due to bankruptcy Article 90 paragraph (2) of the Limited Liability Company Law).
\end{abstract}

Keywords: Responsibility, bankruptcy, directors, limited company

How to Cite: Antonius Faebuadodo Gea, et.al. 2020. Tanggung Jawab Direksi atas Terjadinya Pailit Perseroan Terbatas. 4(1): pp. 83-98. DOI: https://doi.org/ 10.24036/jess/vol4-iss1

\section{Pendahuluan}

Direksi merupakan dewan direktur (board of frectors) yang dapat terdiri atas satu atau beberapa orang direktur. Apabila direksi lebih dari satu orang direktur, maka salah satunya menjadi Direktur Utama dan yang lainnya menjadi direktur atau wakil direktur (Khairandy, 2014). 
Menurut Pasal 1 angka 5 Undang-undang Perseroan Terbatas (UUPT), direksi adalah organ perseroan yang berwenang dan bertanggung jawab penuh atas pengurusan perseroan untuk kepentingan perseroan, sesuai dengan maksud dan tujuan perseroan serta mewakili perseroan baik di dalam maupun di luar pengadilan sesuai dengan ketentuan anggaran dasar. Selanjutnya Pasal 92 ayat (1) UUPT menentukan bahwa direksi menjalankan pengurusan perseroan untuk kepentingan perseroan dan sesuai dengan maksud dan tujuan perseroan. Kemudian Pasal 92 ayat (2) UUPT menentukan bahwa direksi berwenang menjalankan pengurusan tersebut sesuai dengan kebijakan yang dipandang tepat, dalam batas yang ditentukan dalam UUPT dan/atau anggaran dasar. Dari ketentuan-ketentuan di atas dapat disimpulkan bahwa direksi di dalam perseroan memiliki 2 (dua) fungsi, yakni fungsi pengurusan (manajemen) dan fungsi perwakilan (representasi).

Di dalam perseroan tertutup seringkali pemegang saham juga menjadi anggota direksi perseroan yang bersangkutan. Walaupun direktur itu adalah pemegang saham, namun ketika pemegang saham menjadi direktur, maka pemegang saham tersebut pada hubungan kerja dengan perseroan. Dengan perkataan lain, direktur atau anggota direksi tersebut pada dasarnya adalah karyawan perseroan. Sedangkan di dalam perseroan terbuka, seringkali orang yang menjadi anggota direksi adalah orang profesional yang bukan pemegang saham di perseroan yang bersangkutan. Dalam kondisi demikian, anggota murni disebut sebagai pekerja atau karyawan perseroan.

Sebagai konsekuensi dari kedudukan tersebut, maka hubungan hukum antara direksi dan perseroan adalalah hubungan kerja yang tunduk kepada hukum perburuhan atau hukum ketenagakerjaan. Konsekuensi dari hubungan tersebut adalah hak anggota direksi untuk mendapat upah atau gaji dari perseroan. Di dalam Pasal 96 ayat (1) UUPT disebutkan bahwa ketentuan besarnya gaji dan tunjangan anggota direksi ditetapkan berdasar keputusan RUPS. Oleh Pasal 96 ayat (2) UUPT ditentukan bahwa kewenangan RUPS tersebut dapat dilimpahkan kepada dewan komisaris. Kemudian oleh Pasal 96 ayat (3) UUPT ditambahkan bahwa dalam kewenangan tersebut dilimpahkan kepada dewan komisaris, besarnya dan tunjangan anggota direksi ditetapkan berdasar keputusan dewan direksi.

Menurut Khairandy (2014) hubungan antara direksi dan perseroan selain berdasarkan hubungan kerja, direksi juga memiliki hubungan fidusia dengan perseroan. Direksi memiliki kedudukan fidusia (fiduciary position) di dalam perseroan. Tulisan singkat ini akan mengupas dan mendiskusikan tentang tanggung jawab direksi atas terjadinya pailit pada Perseroan Terbatas (PT).

\section{Tinjauan Kepustakaan}

Perseroan yang merupakan badan hukum dalam melaksanakan perbuatan hukum dilakukan oleh pengurusnya. Tanpa adanya pengurus, badan hukum itu tidak akan dapat berfungsi. Ketergantungan antara badan hukum dan pengurus menjadi sebab mengapa antara badan hukum dan pengurus lahir hubungan fidusia (fiduciary duties) di mana pengurus merupakan pihak yang dipercaya bertindak dan menggunakan wewenangnya hanya untuk kepentingan perseroan semata (Kesowo, 1995). 
Kepengurusan perseroan terbatas sehari-hari dilakukan oleh direksi. Keberadaan direksi dalam suatu organ perseroan merupakan suatu keniscayaan. Dengan kata lain, perseroan wajib memiliki direksi. Hal ini dikarenakan perseroan sebagai artificial person, di mana perseroan tidak dapat berbuat apa-apa tanpa adanya bantuan anggota direksi sebagai natural person (Khairandy, 2014). Selain itu, direksi dalam perseroan juga harus memperhatikan hal-hal yang bersifat negatif pada perseroan, seperti unfettered discretion, maksudnya agar direksi jangan sampai terbelenggu oleh keinginan-keinginan membuat kebijakan di luar kewenangannya. Dalam artian ini, direksi harus mampu menolak berbagai intervensi dari pemegang saham yang nemaksanya untuk mengambil kebijakan demi kepentingan atau motif-motif pribadi (Wilarmata, Tanpa Tahun). Karena kedudukan direksi yang bersifat fiduciary, yang oleh UUPT sampai batas-batas tertentu diakui, maka tanggung jawab direksi menjadi sangat tinggi (high degree). Karena tidak hanya bertanggungjawab terhadap ketidakjujuran yang disengaja (dishonesty), tetapi dia juga bertanggungjawab secara hukum terhadap tindakan mismanagement, kelalaian atau gagal atau tidak melakukan sesuatu yang penting bagi perseroan (Fuady, 2003). Pasal 97 ayat (2) UUPT menentukan bahwa setiap anggota direksi wajib dengan iktikad baik dan penuh tanggung jawab menjalankan tugas untuk kepentingan dan usaha perseroan. Dengan demikian direksi bertanggungjawab penuh atas pengurusan perseroan, artinya secara fiduciary harus melaksanakan standard of care. Fiduciary duty adalah tugas yang dijalankan oleh direktur dengan penuh tanggung jawab untuk kepentingan (benefit) orang atau pihak lain (perseroan).

Menurut Fuady (2003), dalam menjalankan tugas fiduciary duties, seorang direksi harus melakukan tugasnya sebagai berikut:

1) dilakukan dengan iktikad baik;

2) dilakukan dengan proper purposes;

3) dilakukan dengan kebebasan yang bertanggungjawab; dan

4) tidak memiliki benturankepentingan (conflict of duty and interest).

Oleh karena itu, apabila terjadi benturan kewajiban (conflict of duty) dan benturan kepentingan pada saat menjalankan perseroan, direksi harus mampu mengelola secara bijak berbagai pertentangan sebagai akibat adanya perberdaan kepentingan para pemegang saham. Namun dalam pelaksanaannya, pengelolaan perbedaan kepentingan ini dapat muncul dalam berbagai bentuk, misalnya membuat berbagai macam perjanjian yang menguntungkan perseroan, tidak menyembunyikan suatu informasi untuk kepentingan pribadi, tidak menyalahgunakan kepercayaan dan tidak melakukan kompetisi yang tidak sehat (Wilarmata, Tanpa Tahun).

Ketentuan normatif mengenai tanggung jawab direksi dalam hal terjadinya kepailitan perseroan terbatas adalah sebagaimana ditentukan dalam Pasal 104 Ayat (2) UUPT Tahun 2007. Pasal 104 Ayat (2) UUPT Tahun 2007 menyatakan bahwa Dalam hal kepailitan sebagaimana dimaksud pada Ayat (1) terjadi karena kesalahan atau kelalaian Direksi dari harta pailit tidak cukup untuk membayar seluruh kewajiban Perseroan dalam ke pailitan tersebut, setiap anggota Direksi secara tanggung renteng bertanggung jawab atas seluruh kewajiban yang tidak terlunasi dari harta pailit tersebut. Kemudian Pasal 104 Ayat (4) menentukan Anggota 
Direksi tidak bertanggung jawab atas kepailitan Perseroan sebagaimana dimaksud pada Ayat (2) apabila dia dapat membuktikan:

1) Kepailitan tersebut bukan karena kesalahan atau kelalaiannya;

2) Telah melakukan pengurusan dengan itikad balk, kehati-hatian, dan penuh tanggung jawab untuk kepentingan Perseroan dan sesuai dengan maksud dan tujuan Perseroan;

3) Tidak mempunyai benturan kepentingan baik langsung maupun langsung atas tindakan pengurusan yang dilakukan; dan

4) Telah mengambil tindakan untuk mencegah terjadinya kepailitan (Shubhan, 2008).

Namun demikian, bukanlah hal yang mudah untuk membuktikan bahwa direksi telah melakukan kesalahan dan/atau kelalaian sehingga menyebabkan suatu perseroan mengalami kebangkrutan yang berujung pada kepailitan.

Dari pengaturan ini, maka sebenarnya ada benang merah antara tanggung jawab direksi perseroan terbatas tidak dalam pailit dan tanggung jawab direksi dalam hal perseroan terbatas mengalami pailit. Dengan demikian, berbagai teori tanggung jawab direksi di atas dapat dipakai pula untuk mengukur tanggung jawab direksi dalam hal perseroan terbatas mengalami kepailitan. Sedangkan Pasal 90 Ayat (3) UUPT adalah merupakan implikasi yuridis dari sifat kolegialitas dari direksi di mana segenap direksi bertanggung jawab secara renteng (jointly and severely). Sehingga bagi anggota direksi yang berkehendak untuk melepaskan tanggung jawab renteng tersebut, maka anggota direksi itu wajib membuktikan mengenai hal itu sebagaimana diatur dalam Pasal 104 ayat (4) UUPT Tahun 2007.

Persoalan lebih lanjut dan ketentuan Pasal 90 Ayat (2) UUPT adalah apa yang dimaksud dengan kesalahan atau kelalaian sehingga menjadikan direksi bertanggung jawab secara pribadi. Mengenai hal ini pendapat dari Sutan Remy Sjahdeiny (1999) bahwa yang dimaksud dengan kesalahan dalam Pasal 90 Ayat (2) UUPT itu ialah kesengajaan, karena dalam Pasal 90 Ayat (2) UUPT itu disebut pula secara tersendiri unsur kelalaian. Dalam hukum dikenal ada tiga tingkat atau derajat kelalaian (culpa), yaitu lata culpa atau kelalaian berat, levis culpa atau kelalaian wajar dan levissima culpa atau kelalaian ringan. Sehubungan dengan pembagian derajat kelalaian tersebut, tingkat kelalaian mana yang dimaksudkan dalam Pasal 90 Ayat (2) UUPT itu? Apakah direksi harus bertanggung jawab secara tanggung renteng sebagaimama dimaksud dalam Pasal 90 Ayat (2) UUPT tersebut hanya apabila tingkat kjelalaiannya adalah kelalaian berat (lata culpa atau gross negligence) atau harus juga bertanggung jawab sekalipun kelalaian itu merupakan kelalaian ringan (levissima culpa). Sutan Remi sependapat dengan sikap pengadilan-pengadilan Amerika Serikat bahwa anggota direksi perseroan dalam menjalankan tugasnya hanya bertanggung jawab apabila kelalaian yang dilakukannya adalah kelalaian berat (gross neg ligence).

\section{Metode Penelitian}

Metode penelitian yang dilakukan dalam penelitian ini adalah metode penelitian normatif. Pemilihan metode ini, sebagai yang ditulis oleh Peter Mahmud Marzuki (2010), karena bahwa penelitian hukum adalah suatu proses untuk menemukan 
aturan hukum, prinsip-prinsip hukum, maupun doktrin-doktrin hukum guna menjawab isu hukum yang dihadapi. Oleh karena itu, pilihan metode penelitian ini adalah penelitian hukum normatif yang berkaitan dengan tanggungjawab direksi terhadap pailit suatu perseroan terbatas.

Metode pendekatan yang dilakukan dalam penelitian ini yaitu: a) pendekatan peraturan perundang-undangan (statute approach); dan b) pendekatan konseptual (conceptual approach). Pendekatan peraturan perundang-undangan (statute approach) adalah pendekatan yang mengkaji dan meneliti peraturan perundangundangan dari strata yang paling tinggi sampai dengan strata peraturan perundangundangan yang paling rendah yang berkaitan dengan tanggungjawab direksi terhadap pailitnya perseroan terbatas. Pendekatan konseptual (conceptual approach) yaitu mengelaborasi beberapa konsep hukum, teori hukum, asas-asas hukum maupun doktrin-doktrin hukum yang relevan guna memecahkan atau menjawab isu hukum atau permasalahan yang ada, yaitu yang berkaitan dengan tanggungjawab direksi terhadap pailitnya perseroan terbatas.

\section{Pembahasan}

\section{Tanggungjawab Direksi Terhadap Kepailitan Perseroan Terbatas}

Tanggung jawab Direksi atas kepailitan Perseroan Terbatas (PT) diatur dalam Pasal 104 ayat (2) UU PT yang menentukan bahwa: "Dalam hal kepailitan sebagaimana dimaksud pada ayat (1) terjadi karena kesalahan atau kelalaian Direksi dan harta pailit tidak cukup untuk membayar seluruh kewajiban Perseroan dalam kepailitan tersebut, setiap anggota Direksi secara tanggung renteng bertanggung jawab atas seluruh kewajiban yang tidak terlunasi dari harta pailit tersebut". Pembuktian adanya unsur kesalahan atau kelalaian menjadi kunci utama dalam menuntut pertanggungjawaban anggota Direksi. Menurut Sutan Remy Sjahdeini (2002), yang dimaksudkan dengan kesalahan dalam Pasal 104 ayat (2) UU PT adalah kesengajaan, karena dalam Pasal 104 ayat (2) UU PT itu disebut pula secara tersendiri unsur kelalaian. Dalam hukum pidana, dikenal ada tiga macam gradasi dari unsur kesengajaan (dolus), yaitu: "Kesengajaan sebagai maksud (oorgmerk); Kesengajaan dengan kesadaran pasti atau keharusan (opzet bij zekerheids of noodzakelijkheids bewustzijn); Kesengajaan dengan menyadari kemungkinan (dolus eventualis)" (Sianturi, 1996). Sedangkan unsur kealpaan/kelalaian (culpa) juga mempunyai tiga macam gradasi, antara lain: "Kealpaan yang berat (culpa lata); Kealpaan yang wajar (culpa levis); Kealpaan yang ringan (culpa levissima)" (Sastrawidjaja, 1996). Sjahdeini (2002) sependapat dengan sikap-sikap di pengadilan-pengadilan Amerika Serikat bahwa seorang anggota Direksi Perseroan dalam menjalankan tugasnya hanya bertanggung jawab apabila kelalaian yang dilakukan adalah kelalaian berat (gross negligence). Meskipun demikian, tidak mudah untuk membedakan mana perbuatan hukum Direksi yang bersifat kelalaian ringan dan mana perbuatan Direksi yang bersifat kelalaian berat, karena penilaian tersebut merupakan sesuatu yang bersifat subjektivitas (Jono, 2017).

Tanggung jawab Direksi sehubungan dengan kepailitan PT dapat dibedakan sebagai berikut:

1) Tanggung jawab pidana (criminal liability) 
Ketentuan pidana yang mengatur pertanggungjawaban pidana Direksi yang berhubungan dengan kepailitan PT terdapat dalam Buku Kedua tentang Kejahatan, Bab XXVI Perbuatan Merugikan Pemiutang atau Orang yang Mempunyai Hak dari KUHP.

2) Tanggung jawab perdata (civil liability)

Dalam UU PT terdapat beberapa ketentuan yang secara langsung mengatur hubungan Direksi PT dengan masalah kerugian/kepailitan yang terjadi, yaitu dalam Pasal 93 ayat (1) huruf a UU PT Tahun 2007, Pasal 97 ayat (3) UU PT 2007, Pasal 104 ayat (2) dan (4) UU PT Tahun 2007. Dengan demikian, tanggung jawab pengurusan Perseroan dipercayakan dan dipikul oleh setiap anggota Direksi tanpa terkecuali, baik kesalahan maupun kelalaian seorang atau lebih anggota Direksi berdampak bahwa seluruh anggota Direksi harus memikul tanggung jawab secara tanggung renteng. Beban pembuktian dalam hal terjadinya kepailitan yang diduga karena kesalahan atau kelalaian Direksi Perseroan berdasarkan Pasal 97 ayat (3) UU PT Tahun 2007, meletakkan beban pembuktian atas adanya kesalahan atau kelalaian Direksi sehingga Direksi tersebut harus bertanggungjawab secara pribadi, terletak pada pihak yang mendalilkannya mengenai adanya kesalahan atau kelalaian tersebut. Jika pihak yang mendalilkan berhasil untuk membuktikan kesalahan atau kelalaian Direksi Perseroan, maka setiap anggota Direksi secara tanggung renteng bertanggung jawab atas kerugian akibat kepailitan Perseroan yang tidak dapat ditutup oleh kekayaan Perseroan.

Rudhi Prasetya (2002) menyatakan bahwa jika berbicara mengenai pertanggungjawaban, maka dapat dilihat dari hubungan ekstern dan segi hubungan intern. Tanggung jawab ekstern adalah tanggung jawab sebagai dampak dalam hubungan dengan pihak luar. Sedangkan tanggung jawab intern adalah dampak dari hubungan si pengurus sebagai organ terhadap organ lainnya, yaitu institusi komisaris dan/atau rapat umum pemegang saham. Sedangkan jika dilihat dari substansinya, maka tanggung jawab direksi PT dibedakan setidaktidaknya menjadi empat kategori, yakni:

1) tanggung jawab berdasarkan prinsip fiduciary duties dan duty to skill and care;

2) tanggung jawab berdasarkan doktrin menejemen ke dalam (indoor menajemen rule);

3) tanggung jawab berdasarkan prinsip Ultra vires; dan

4) tanggung jawab berdasarkan prinsip piercing the corporate veil.

Dalam kaitan dengan kepailitan suatu PT, maka prinsip doktrin piercing the corporate veil ini sangat erat berkait. Doktrin piercing the corporate veil ini seperti yang dianut dalam UU PT 2007 tersebut hampir sama dengan asas misbruik van rechtspersonen seperti yang dianut di Belanda. Rudhi Prasetya menyatakan bahwa asas misbruik van rechtspersonen hanya dapat digunakan jika sudah sampai pada taraf pailit. Menurut Schilfgaarde dalam bukunya misbruik van rechtspersonen sebagaimana yang disitir oleh Rudhi Prasetya bahwa dalam rangka menanggulangi penyalahgunaan badan hukum, di negara 
Belanda diterbitkan Wet Op Misbruik van Rechtspersonen. Menurut UndangUndang Belanda ini:

1) manakala suatu badan hukum jatuh pailit sehingga kekayaan badan tidak cukup membayar lunas utangnya;

2) dan ternyata pengurus nyata-nyata tidak melaksanakan tugasnya secara pantas (wanner het bertuur zijn taak kennelijk on behoorlijk heeft vervuld);

3) dan dapat diperkirakan penyebab utama dari kepailitan tersebut oleh karena ketidakpantasan pengurus dalam menjalankan tugasnya itu (en aanemelijk is dat dit een belaangrijke oorzaak is van het faillisement);

4) maka pengurus harus ikut bertanggung jawab secara pribadi, artinya menjadi tanggung jawab pengurus pribadi atas sisa utang yang masih belum cukup terbayar dari harta kekayaan badan yang bersangkutan;

5) dan dalam hal ini yang dimaksud dengan pengurus yang harus ikut bertanggung jawab secara pribadi itu bukan saja dalam arti formal di atas kertas menurut statuta atau akta, akan tetapi dengan pengertian pengurus di sini harus ditafsirkan termasuk pula orang-orang yang menurut kenyataan menentukan dalam mengambil keputusan kebijaksanaan perusahaan yang bersangkutan. Yang dimaksud dengan "orang-orang yang menurut kenyataan menentukan dalam mengambil keputusan kebijaksanaan perusahaan yang bersangkutan", dapat berupa para komisaris atau para pemegang saham (Prasetya, 2002).

Direksi dapat dimintakan pertanggungjawaban pribadi atas kepailitan perseroan berlandaskan dua asas hukum yaitu:

1. Asas pertanggungjawaban jabatan.

Hubungan Direksi dan perseroan adalah karena Direksi mempunyai jabatan atau kedudukan selaku wakil perseroan, yang bersumber dari wewenang formal (formal authority) (Sinaga, 2012). Jabatan atau kedudukan tersebut merupakan wewenang formal, karena hal itu didasarkan pada Pasal 92 juncto Pasal 97 UU PT 2007. Menurut pasal tersebut, Direksi diberikan wewenang atau kekuasaan untuk melakukan tugas pengurusan dan perwakilan. Tugas tersebut seyogyanya dilakukan direksi berdasarkan fiduciary duties. Salah satu bagian utama dalam fiduciary duties adalah bahwa Direksi melakukan kekuasaan atau tugasnya dengan itikad baik demi kepentingan perusahaan (duty to exercise power bona fide in the interest of the company). Karena itu, pertanggungjawaban direksi atas kepailitan PT dapat dilihat dari sudut asas pertanggungjawaban jabatan (function liability principle) ini. Sehubungan dengan jabatan tersebut, Fred B.G. Tumbuan (2007) berpendapat bahwa persetujuan yang diberikan Dewan Komisaris kepada Direksi atas tindakan tertentu tidak membebaskan Direksi dari tanggung jawabnya karena masing-masing organ mempunyai tugas yang mandiri dan karena itu harus mempertanggungjawabkannya secara sendiri.

2. Asas perlindungan kreditor (creditor protection principle).

Menurut azas ini, ada kaitan antara penerapan ultra-vires doctrine dan perlindungan kreditor, yang mana ultra-vires doctrine adalah ajaran mengenai perbuatan diluar kewenangan seseorang (Sjahdeini, 2002). Dalam kaitan dengan PT, hal itu berarti 
perbuatan Direksi dalam melaksanakan tugasnya yang ternyata berada diluar maksud dan tujuan perseroan sehingga harus dipertanggungjawabkan kepada pihak yang dirugikan (kreditor). Ultra-vires doctrine dimaksudkan untuk melindungi kreditor apabila pada waktunya aset perseroan tidak mencukupi untuk melunasi kewajibannya kepada kreditor. Dalam perlindungan kreditor, kepailitan sudah jelas mengelompokkan kreditor menjadi kreditor prefen, kreditor separatis dan kreditor konkuren. Pembagian ini dimaksudkan agar usaha kreditor untuk mendapatkan jaminan, apabila debitor cedera janji, dihormati dan dihargai.

Direksi perseroan dapat diminta pertanggungjawaban pribadinya atas kepailitan PT. Pertanggungjawaban tersebut harus didasarkan pada peristiwa hukum sebagai persyaratan utama untuk menggerakkan pemberlakuan pasalpasal UU PT maupun UU PKPU. Menurut Satjipto Rahardjo (2006), peristiwa hukum adalah : "Suatu kejadian dalam masyarakat yang menggerakkan suatu peraturan hukum tertentu sehingga ketentuan dalam peraturan itu diwujudkan. Peristiwa hukum tersebut terdapat dalam sistem hukum yang harus dikaitkan dengan berbagai urutan kejadian, peraturan atau putusan pengadilan serta sikap masyarakat sehingga semua merupakan suatu keseluruhan yang bersambung satu sama lain untuk menentukan pertanggungjawaban Direksi (Sinaga, 2012).

Pertanggungjawaban Direksi PT akan muncul apabila dalam pengurusan sesuai dengan Pasal 104 ayat (2) UU PT, ternyata PT jatuh pailit dan harta debitor pailit berada dalam keadaan insolven. Selain itu, dalam kepailitan harus ditemukan unsur kesalahan Direksi perseroan dalam melakukan pengurusan perseroan tersebut. Berdasarkan UU PT dan UU KPKPU, maka permintaan pertanggungjawaban Direksi terhadap kreditor akan muncul dengan empat peristiwa hukum sebagai berikut:

1) Perseroan dinyatakan pailit berdasarkan putusan pengadilan yang berkekuatan hukum tetap dan harta pailit perseroan berada dalam keadaan insolven.

2) Rencana perdamaian ditolak dalam permohonan PKPU.

3) Harta debitor pailit tidak cukup untuk melunasi kewajiban (utang) kepada kreditor.

4) Kepailitan Perseroan karena kelalaian atau kesalahan Direksi.

Pasal 104 ayat (2) UU PT mengatur bahwa Direksi yang terbukti telah melakukan kesalahan atau kelalaian dalam pengurusan perseroan dan karena perbuatan tersebut perseroan menjadi pailit maka kreditor dapat meminta pertanggungjawaban Direksi secara pribadi. Sebaliknya, apabila Direksi melakukan pengurusan perseroan secara benar dan sungguh-sungguh demi dan untuk kepentingan perseroan, mereka tidak dapat diminta pertanggungjawaban sehingga kewajiban pihak yang dirugikanlah yang akan membuktikan apakah Direksi melakukan pengurusan perseroan dengan tidak benar dan tidak sungguhsungguh. Pembuktian sebaliknya ini dilihat dari adagium dalam bahasa latin bahwa omnia praesumuntur legitime facta donec probetur in contrarium. Artinya, segala hal diasumsikan telah dilakukan sesuai dengan hukum hingga dibuktikan hal yang sebaliknya. Apabila dilihat dari teori perundang-undangan, tanggung jawab Direksi atas kesalahan atau kelalaiannya merupakan norma 
hukum sekunder (Indriati, 2007). Norma hukum sekunder adalah norma hukum yang berisi cara penanggulangan apabila norma hukum primer tidak dipenuhi. Norma hukum primer adalah norma hukum yang berisi aturan tentang bagaimana seseorang (dalam ini Direksi) bertindak dalam menjalankan perseroan sebagaimana yang ditetapkan dalam Pasal 92 juncto Pasal 97 UU PT. Dari pengaturan tersebut dapat dilihat ada 2 (dua) perbuatan yang dikategorikan sebagai perbuatan yang bertentangan dengan hukum yaitu kelalaian dan kesalahan. Sebagai akibat kelalaian atau kesalahan, terhadap pihak yang melakukan perbuatan tersebut akan dituntut ganti rugi atau sanksi (sanction) (Sinaga, 2012).

Menurut Subekti (2005), pengertian lalai dikaitkan dengan perjanjian dengan debitor dimana debitor tidak memenuhi kewajibannya atau terlambat memenuhi kewajibannya atau telah memenuhi kewajibannya namun tidak seperti yang diperjanjikan. Selanjutnya, agar terjadi kewajiban untuk memberi ganti rugi, maka pihak yang berutang dapat dituntut dengan dinyatakan lalai. Dapat disimpulkan bahwa kelalaian adalah perbuatan yang timbul karena perjanjian yang diatur dalam buku III BW. Sementara itu dalam melakukan pengurusan perseroan, khususnya melakukan tindakan dengan pihak ketiga, maka Direksi bertindak untuk dan atas nama perseroan. Apabila isi perjanjian tidak dapat dipenuhi maka pihak yang tidak berprestasi atau lalai adalah perseroan. Dengan kata lain, perseroan yang sebetulnya yang menjadi pihak dalam perbuatan tersebut, oleh karena itu pihak yang dituntut adalah perseroan dan bukan direksinya (Subekti, 1984).

Pemakaian kata kesalahan dikaitkan dengan adanya tindakan hukum seseorang, tetapi bukan karena wanprestasi atas kontrak (perjanjian), melainkan perbuatan melawan hukum yang digunakan dalam sistem hukum Belanda atau Civil Law (Fuady, 2005). Dalam sistem hukum Common Law, dikenal penal law atau law of torts, yang dapat dikaitkan dengan kesalahan dalam hukum sipil perdata (civil law), sebagaimana kejahatan hukum pidana (Suherman, 2004). Sebagai bagian dari hukum perdata, law of torts mewajibkan orang yang melakukan kesalahan (a private wrong) memberikan kompensasi atau perbuatannya (Sinaga, 2012). Law of torts memberikan kewajiban kepada seseorang, maksudnya untuk melakukan perbuatan. Sebagai perbandingan dalam tort law, kewajiban orang dipaksakan oleh masyarakat. Berbeda halnya dalam hukum perjanjian, kewajiban dilakukan para pihak (self imposed). Selain itu, tort law dimaksudkan untuk memberikan kompensasi kepada korban sebagai akibat dari tindakan pihak lain. Sehingga dapat disimpulkan bahwa lingkup perbuatan yang akan dipertanggungjawabkan secara pribadi oleh direksi perseroan adalah kelalaian karena direksi tidak memenuhi isi perjanjian dan kesalahan karena direksi melakukan perbuatan melawan hukum. Kesalahan atau kelalaian dapat disebut sebagai perbuatan yang bertentangan dengan hukum atau melawan hukum (perbuatan melanggar hukum) (Prodikoro, 2000). Perbuatan melawan hukum adalah terjemahan dari onrechtmatige daad yang diatur dalam Pasal 1365 BW. 


\section{Akibat Hukum Terhadap Kepailitan Perseroan}

a. Akibat Kepailitan Terhadap Debitur Pailit dan Hartanya

Dalam lampiran pasal 19 UUK No. 4 Tahun 1998 jo Pasal 21 UUK NO. 37 Tahun 2004, kepailitan meliputi seluruh kekayaan debitur pada saat pernyataan pailit itu diputuskan beserta semua kekayaan yang diperoleh selama kepailitan itu. Menurut pasal 22 UUK No. 37 Tahun 2004, ketentuan sebagaimana dimaksud dalam Pasal 21 tidak berlaku terhadap:

1) Benda, termasuk hewan yang benar-benar dibutuhkan oleh Debitor sehubungan dengan pekerjaannya, perlengkapannya, alat-alat medis yang dipergunakan untuk kesehatan, tempat tidur dan perlengkapannya yang dipergunakan oleh Debitor dan keluarganya, dan bahan makanan untuk 30 (tiga puluhan) bagi Debitor dan keluarganya, yang terdapat di tempat itu;

2) Segala sesuatu yang diperoleh Debitor dan pekerjaannya sendiri sebagai penggajian dan suatu jabatan atau jasa, sebagai upah, pensiun, uang tunggu atau uang tunjangan, sejauh yang ditentukan oleh Hakim Pengawas; atau

3) Uang yang diberikan kepada Debitor untuk memenuhi suatu kewajiban memberi nafkah menurut undang-undang.

Yang dimaksud semua kekayaan yang diperoleh selama kepailitan, misalnya warisan Menurut Pasal 40 UUK No. 37 Tahun 2004, segala warisan yang selama kepailitan menjadi hak debitur pailit, tidak boleh diterima oleh kurator, kecuali apabila menguntungkan harta pailit. Sedangkan untuk menolak semua warisan, kurator memerlukan izin dari hakim pengawas.

Berdasarkan ketentuan lampiran pasal 19 UUK Tahun 1998 jo pasal 21 UUK Tahun 2004 tersebut, yang dinyatakan pailit adalah seluruh kekayaan debitur, bukan pribadinya. Karena itu menurut pasal 24 UUK Tahun 2004, dengan dinyatakannya pailit, si pailit demi hukum kehilangan haknya untuk berbuat bebas terhadap kekayaannya yang termasuk dalam kepailitan, begitu pula haknya untuk mengurus, sejak tanggal putusan pailit diucapkan. Tanggal putusan dihitung sejak pukul 00.00 waktu setempat. Yang dimaksud "waktu setempat" adalah waktu tempat putusan pernyataan pailit diucapkan oleh Pengadilan Niaga, misalnya putusan diucapkan di Surabaya pada tanggal 24 Desember 2005 pukul 13.000 WIB, maka putusan tersebut dihitung mulai berlaku sejak pukul 00.00.

Apabila senbelum putusan pernyataan pailit diucapkan telah dilaksanakan transfer dana melalui bank atau lembaga selain bank pada tanggal putusan sebagaimana tersebut di atas, transfer tersebut wajib diteruskan. Transfer dana melalui Bank perlu dikecualikan hal ini semata-mata untuk menjamin kelancaran dan kepastian sistem transfer melalui bank.

\section{b. Akibat Kepailitan Terhadap Eksekusi Atas Harta Kekayaan Debitur Pailit}

Di dalam ketentuan lampiran UUK pasal 32 Jo pasal 31 ayat (1) UUK No. 37 Tahun 2004 disebutkan, putusan pernyataan pailit berakibat bahwa segala putusan hakim menyangkut setiap bagian harta kekayaan debitur yang telah dimulai sebelum kepailitan, harus segera dihentikan dan sejak itu tidak ada suatu putusan yang dapat dilaksanakan termasuk atau juga dengan menyandera Debitor. Dalam penjelasan ayat (1) disebutkan bahwa dengan tidak mengurangi ketentuan Pasal 56, Pasal 57, 
dan Pasal 58, ketentuan ini tidak berlaku bagi Kreditor sebagaimana dimaksud dalam Pasal 55, yakni bahwa setiap kreditor pemegang gadai, jaminan fidusia, hak tanggungan, hipotik atau hak agunan atas kebendaan lainnya dapat mengeksekusi haknya seolah-olah tidak terjadi kepailitan.

Sementara itu dalam pasal 56 disebutkan bahwa hak eksekusi Kreditor sebagaimana dimaksud dalam Pasal 55 ayat (1) dan hak pihak ketiga untuk menuntut hartanya yang berada dalam penguasaan Debitor Pailit atau Kurator, ditangguhkan untuk jangka waktu paling lama 90 (sembilan puluh) hari sejak tanggal putusan pernyataan pailit diucapkan. Penangguhan mana tidak berlaku terhadap tagihan Kreditor yang dijamin dengan uang tunai dan hak Kreditor untuk memperjumpakan utang. Selama jangka waktu penangguhan tersebut, Kurator dapat menggunakan harta pailit berupa benda tidak bergerak maupun benda bergerak atau menjual harta pailit yang berupa benda bergerak yang berada dalam penguasaan Kurator dalam rangka kelangsungan usaha Debitor, dalam hal telah diberikan perlindungan yang wajar bagi kepentingan Kreditor atau pihak ketiga.

Dalam pasal 57 diatur tentang jangka waktu sebagaimana dimaksud dalam Pasal 56 ayat (1) berakhir demi hukum pada baat kepailitan diakhiri lebih cepat atau pada saat dimulainya keadaan insolvensi sebagaimana dimaksud dalam Pasal 173 yat (1) (lihat UUK No. 37 Tahun 2004). Kreditor atau pihak ketiga yang haknya ditangguhkan dapat mengajukan permohonan kepada Kurator untuk mengangkat penangguhan atau mengubah syarat penangguhan tersebut. Apabila Kurator menolak permohonan maka, Kreditor atau pihak ketiga dapat mengajukan permohonan tersebut kepada Hakim Pengawas. Kemudian hakim Pengawas dalam waktu paling lambat 1 (satu) hari setelah permohonan tersebut diterima, wajib memerintahkan Kurator untuk segena memanggil dengan surat tercatat atau melalui kurir, Kreditor dan pihak ketiga untuk didengan pada sidang pemeriksaan atas permohonan tersebut. Selanjutnya Hakim Pengawas wajib membenikan penetapan atas permohonan dalam waktu paling lambat 10 (sepuluh) hari setelah permohonan diajuk kepada Hakim Pengawas.

Terhadap putusan Pengadilan sebagaimana dimaksud pada ayat (2) tidak dapat diajukan upaya hukum apapun termasuk Peninjauan Kembali. Semua penyitaan yang telah dilakukan menjadi hapus dan jika diperlukan Hakim Pengawas harus memerintahkan pencoretannya (pasal 31 ayat (2) UUK No. 37 Tahun 2004). Yang dimaksud dengan "jika diperlukan Hakim Pengawas harus memerintahkan pencoretannya" antara lain pencoretan terhadap penyitaan tanah atau kapal yang terdaftar. Selanjutnya, Ayat (3) nya menyebutkan, dengan tidak mengurangi berlakunya ketentuan sebagaimana dimaksud dalam Pasal 93, Debitur yang sedang dalam penahanan harus dilepaskan seketika setelah putusan pernyataan pailit diucapkan. Yang dimaksud dengan "penahanan" dalam ketentuan ini adalah gijzeling (Prodikoro (2002).

Selama kepailitan Debitor tidak dikenakan uang paksa. Uang paksa disini mencakup uang paksa yang dikenakan sebelum putusan pernyataan pailit diucapkan (pasal 32). Disebutkan dalam pasal 93 ayat (1)-(5) bahwa:

(1) Pengadilan dengan putusan pernyataan pailit atau setiap waktu setelah itu, atas usul Hakim Pengawas, permintaan Kurator, atau atas permintaan seorang Kreditor atau Iebih dan setelah mendengar Hakim Pengawas, dapat 
memerintahkan supaya Debitor Pailit ditahan, baik ditempatkan di Rumah Tahanan Negara maupun di rumahnya sendiri, di bawah pengawasan jaksa yang ditunjuk oleh Hakim Pengawas.

(2) Perintah penahanan sebagaimana dimaksud pada ayat (1) dilaksanakan oleh Jaksa yang ditunjuk oleh Hakim Pengawas.

(3) Masa penahanan sebagaimana dimaksud pada ayat (2) berlaku paling lama 30 (tiga puluh) hari terhitung sejak penahanan dilaksanakan.

(4) Pada akhir tenggang waktu sebagaimana dimaksud pada ayat (3), atas usul Hakim Pengawas atau atas permintaan Kurator atau seorang Kreditor atau lebih dan setelah mendengar Hakim Pengawas, Pengadilan dapat memperpanjang masa penahanan setiap kali untuk jangka waktu paling lama 30 (tiga puluh) hari.

(5) Biaya penahanan dibebankan kepada harta pailit sebagai utang harta pailit.

\section{Akibat Kepailitan Terhadap Perjanjian Timbal Balik Yang Dilakukan Sebelum Kepailitan}

Kepailitan meliputi seluruh utang dan piutang debitur pada saat pernyataan pailit dilakukan (lampiran UUK pasal 19 jo pasal 21 UUK No. 37 Tahun 2004). Dengan adanya pernyataan pailit, maka kemudian pengurusan harta pailit dilakukan oleh kurator. Bagaimana halnya dengan hak dan kewajiban yang harus dipenuhi oleh debitur pailit sebelum pernyataan pailit dilakukan?

Menurut Ketentuan pasal 36 ayat (1)-(5) UUK No. 37 Tahun 2004, dalam hal pada saat putusan pernyalaan pailit diucapkan, terdapat perjanjian timbal balik yang belum atau baru sebagian dipenuhi, pihak yang mengadakan perjanjian dengan debitor dapat meminta kepada Kurator untuk memberikan kepastian tentang kelanjutan pelaksanaan perjanjian tersebut dalam jangka waktu yang disepakati oleh kurator dan pihak tersebut.

Dalam hal kesepakatan mengenaj jangka waktu tidak mencapai, Hakim Pengawas menetapkan jangka waktu tersebut. Apabila dalam jangka waktu tersebut diatas, Kurator tidak memberikan jawaban atau tidak bersedia melanjutkan melaksanaan perjanjian tersebut maka perjanjian berakhir dan pihak sebagaimana dimaksud pada ayat (1) dapat menuntut ganti rugi dan akan diperlakukan sebagai kreditor konkuren. Apabila Kurator menyatakan kesanggupannya maka Kurator wajib memberi jaminan atas kesanggupan untuk melaksanakan perjanjian tersebut. Ketentuan sebagaimana tersebut pada ayat (1), ayat (2), ayat (3), dan ayat (4) tidak berlaku terhadap perjanjian yang mewajibkan Debitor melakukan sendiri perbuatan yang diperjanjikan.

Apabila dalam perjanjian sebagaimana dimaksud dalam Pasal 36 telah diperjanjikan penyerahan benda dagangan yang biasa diperdagangkan dengan suatu jangka waktu dan pihak yang harus menyerahkan benda tersebut sebelum penyerahan dilaksanakan dinyatakan pailit maka perjanjian menjadi hapus dengan diucapkannya putusan pernyataan pailit, dan dalam hal pihak lawan dirugikan karena penghapusan maka yang bersangkutan dapat mengajukan din sebagai kreditor konkuren untuk mendapatkan ganti rugi. Dalam hal harta pailit dirugikan karena penghapusan cebagaimana dimaksud pada ayat (1) maka pihak lawan wajib membayar ganti kerugian tersebut (pasal 37 ayat (1)-(2)UUK No. 37 Tahun 2004). 
Dalam hal adanya perjanjian kerja, maka Pekerja yang bekerja pada Debitor dapat memutuskan hubungan kerja, dan sebaliknya Kurator dapat memberhentikannya dengan mengindahkan jangka waktu menurut persetujuan ketentuan perundang-undangan yang berlaku, dengan pengertian bahwa hubungan kerja tersebut dapat diputuskan dengan pemberitahuan paling singkat 45 (empat lima) hari sebelumnya.

\section{Akibat Kepailitan Terhadap Kewenangan Berbuat Debitur Pailit Dalam Bidang Hukum Harta Kekayaan}

Setelah ada putusan pernyataan pailit, debitur dalam batas-batas tertentu masih dapat melakukan perbuatan hukum dalam bidang hukum kekayaan sepanjan perbuatan tersebut akan mendatangkan keuntungan bagi harta pailit. Sebaliknya apabila perbuatan hukum tersebut akan merugikan harta pailit, kurator dapat minta pembatalan atas perbuatan hukum yang dilakukan oleh debitur pailit. Pembatalan tersebut bersifat relatif, artinya hal itu hanya dapat digunakan untuk kepentingan harta pailit sebagaimana diatur dalam Pasal 41 UUK No. 37 Tahun 2004.

Menurut Pasal 43 UUK No. 37 Tahun 2004, hibah yang dilakukan debitur dapat dimintakan pembatalannya, apabila kurator dapat membuktikan bahwa pada saat hibah tersebut dilakukan, debitur mengetahui atau patut mengetahui bahwa tindakan tersebut akan mengakibatka kerugian bagi kreditur. Dengan ketentuan tersebut, maka kurator tidak perlu membuktikan bahwa penerima hibah mengetahui atau patut mengetahui bahwa tindakan tersebut akan mengakibatkan kerugian bagi kreditur. Kecuali apabila dapat dibuktikan sebaliknya, debitur danggap mengetahui atau patut menngetahui bahwa hibah tersebut merugikan kreditur apabila hibah tersebut dilakukan dalam jangka waktu satu tahun sebelum putusan pernyataan pailit ditetapkan.

Selanjutnya dalam pasal 45 UUK No. 37 Tahun 2004, ditentukan mengenai pembatalan pembayaran utang oleh debitur palit hanya dapat dilakukan apabila dapat dibuktikan bahwa penerima pembayaran itu mengetahui bahwa debitur pailit telah mengajukan laporan permohonanan pernyataan pailit, atau bila pembayaran itu merupakan akibat suatu perundingan antara debitur dan kreditur, serta pembayaran itu memberikan keuntungan kepada kreditur yang bersangkutan yang mendahulukan pembayaran diatas para kreditur lainnya.

Akan tetapi penagihan kembali tersebut tidak dapat dilakukan dan seorang pemegang surat perintah pembayaran atau surat pemegang-pemegangnya dahulu, diwajibkan menerima pembayaran. Kecuali apabila dapat dibuktikan bahwa suratsurat berharga tersebut dikeluarkan karena penerima pembayaran mengetahui bahwa debitur telah mengajukan permohonan pailit atau surat berharga tersebut dikeluarkan atas perundingan antara debitur dan keditur, maka dalam hal mi orang yang mendapat keuntungan dan pengeluaran surat berharga itu wajib mengembalikan jumlah tersebut kepada harta pailt.

\section{Akibat Kepailitan Terhadap Barang Jaminan}

Menurut ketentuan dalam pasal 55 jo pasal 56 UUK No. 37 Tahun 2004 disebutkan bahwa setiap kreditur pemegang gadai, jaminan fidusia, hak tanggungan, hipotek, 
atau hak agunan atas kebendaan lainnya, dapat mengeksekusi haknya seolah-olah tidak tenjadi kepailitan. Hak kreditur untuk mengeksekusi barang agunan dan hak pihak ketiga untuk menuntut hartanya yang berada dalam penguasan debitur yang pailit atau kurator, ditangguhkan untuk jangka waktu paling lama 90 (sembilan puluh) hari terhitung sejak tanggal putusan pailit diucapkan. Penangguhan ini bertujuan untuk:

1) Untuk memperbesar kemungkinan tercapainya perdamaian atau

2) Untuk mernperbesar kemungkinan mengoptimalkan harta pailit atau

3) Untuk memungkinkan kurator melaksanakan tugas secara optimal.

Selama berlangsungnya jangka waktu penangguhan, segala tuntutan hukum untuk memperoleh pelunasan atas suatu piutang tidak dapat diajukan dalam sidang badan peradilan, dan baik kreditur maupun pihak ketiga dimaksudkan dilarang mengeksekusi atau memohon sita atas barang yang menjadi agunan. Penangguhan tersebut tidak berlaku terhadap tagihan Kreditor yang dijaminkan dengan uang tunai dan hak Kreditor untuk memperjumpakan utang. Termasuk dalam pengecualian terhadap penangguhan dalam hal ini adalah Kreditor yang timbul dan perjumpaan utang (set off) yang merupakan bagian atau akibat dari mekanisme transaksi yang terjadi di Bursa Efek dan Bursa Perdagangan Berjangka (Pasal 56 ayat (2) UUK No. 37 Tahun 2004).

Selama jangka waktu penangguhan yaitu 90 hari sejak putusan pailit ditetapkan, kurator dapat menggunakan harta pailit berupa benda tidak bergerak maupun benda bergerak atau menjual harta pailit yang berupa benda bergerak yang berada dalam penguasaan Kurator dalam rangka kelangsungan usaha debitur, sepanjang untuk itu telah diberikan perlindungan yang wajar bagi kepentingan kreditur atau pihak ketiga yang menuntut hartanya yang berada dalam pengawasan debitur pailit atau kurator (pasal 56 ayat (3) UUK No. 37 tahun 2004).

Dalam penjelasan ayat (3) disebutkan bahwa, Harta pailit yang dijual oleh Kurator terbatas pada barang persediaan (inventory) dan atau benda bergerak (current assets), meskipun harta pailit tersebut dibebani dengan hak agunan tas kebendaan. Sedangkan yang dimaksud dengan perlindungan yang wajar adalah perlindungan yang perlu diberikan untuk melindungi kepentingan kreditur atau pihak ketiga yang berhak ditangguhkan. Dengan pengalihan harta yang bersangkutan, hak kebendaan tesebut dianggap berakhir demi hukum. Perlindungan yang dimaksud antara lain berupa:

1) Ganti rugi atas terjadiya penurunan nilai hara pailit;

2) Hasil penjualan bersih

3) Hak kebendaan pengganti

4) Imbalan yang wajar dan adil serta pembayaran tunai (utang yang dijamin) lainnya.

\section{Penutup}

Pada prinsipnya Direksi tidak bertanggung jawab secara pribadi terhadap perbuatan yang dilakukan untuk dan atas nama perseroan berdasarkan wewenang yang dimilikinya. Hal ini karena perbuatan Direksi dipandang sebagai perbuatan 
Perseroan yang merupakan subjek hukum mandiri sehingga perseroanlah yang bertanggung jawab terhadap perbuatannya perseroan itu sendiri yang dalam hal ini direpresentasikan oleh Direksi. Lingkup perbuatan yang akan dipertanggungjawabkan secara pribadi oleh direksi perseroan adalah kelalaian karena direksi tidak memenuhi isi perjanjian dan kesalahan karena direksi melakukan perbuatan melawan hukum.

Kepailitan Badan Hukum Perseroan Terbatas adalah kepailitan dirinya sendiri bukan kepailitan para pengurusnya, walaupun kepailitan itu terjadi karena adanya kelalaian dari para pengurusnya. Sehingga seharusnya pengurus tidak dapat dimintai pertanggungjawabannya secara tanggung renteng atas adanya kerugian karena kelalaiannya dan hanya dapat dimintai pertangungjawaban apabila kekayaan perseroan tidak cukup untuk menutup kerugian akibat kepailitan (Pasal 90 ayat (2) UUPT). Kelanjutan usaha dari perseroan terbatas pailit tergantung dari cara pandang Kurator serta kreditur atas prospek usaha debitur pailit di masa datang, kepailitan perseroan terbatas demi hukum tidak membubarkan perseroan terbatas. Pembubaran perseroan terbatas setelah putusan pailit dibacakan hanya dapat dimintakan penetapan pengadilan oleh kreditur dengan alasan perseroan tidak mampu membayar hutangnya setelah dinyatakan pailit atau harta kekayaan perseroan tidak cukup untuk melunasi seluruh hutangnya setelah pernyataan pailit dicabut. Hal mana juga ditegaskan di dalam penjelasan UUK dan PKPU bahwa asas di dalam Undang-undang ini di antaranya adalah asas kelangsungan usaha yang artinya bahwa kepailitan tidak demi hukum menjadikan perseroan bubar.

\section{DAFTAR KEPUSTAKAAN}

Fuady, Munir. (2003). Perseroan Terbatas Paradtgma Baru. Bandung: Citra Aditya Bakti.

Fuady, Munir. (2005). Perbuatan Melawan Hukum. Bandung: Citra Aditya Bakti.

Indriati, Maria Farida. (2007). Ilmu Perundang-Undangan 1. Yogyakarta: Kanisius.

Jono. (2017). Hukum Kepailitan. Cetakan Kelima. Jakarta: Sinar Grafika.

Kesowo, Bambang. (1995). Fiduciary Dimes Direksi Perseroan Terbatas Menurut Undang-Undang No. 1 Tahun 1995. Newsletter. No. 23/VI/Desember 1995.

Khairandy, Ridwan. (2014). Hukum Perseroan Terbatas. Yogyakarta: FH UII Press.

Marzuki, Peter Mahmud. (2010). Penelitian Hukum. Jakarta: Kencana.

Prasetya, Rudhi. (2002). Maatschap, Firma dan Persekutuan Komanditer. Bandung:Citra Aditya.

Prodikoro, Wirjono. (2000). Perbuatan Melanggar Hukum. Bandung: Mandar Maju.

Rahardjo, Satjipto. (2006). Ilmu Hukum. Bandung: Citra Aditya Bakti. 
Sastrawidjaja, Sofjan. (1996). Hukum Pidana (Asas Hukum Pidana Sampai Dengan Alasan Peniadaan Pidana). Bandung: Armico.

Shubhan, M. Hadi. (2008). Hukum Kepailitan Prinsip, Norma, dan Praktik di Peradilan. Jakarta: Kencana.

Sianturi, S. R. (1996). Asas-Asas Hukum Pidana di Indonesia dan Penerapannya. Jakarta: Alumni.

Sinaga, V. Harlen. (2012). Batas-Batas Tanggung Jawab Perdata Direksi. Cetakan Kesatu. Jakarta: Adinatha Mulia.

Sjahdeini, Sutan Remy (2002). Hukum Kepailitan: Memahami Failissementsverordening Juncto Undang-Undang Nomor 4 Tahun 1998. Jakarta: Grafiti.

Subekti. (1984). Aneka Perjanjian. Bandung: Alumni.

Subekti. (2005). Pokok-Pokok Hukum Perdata. Jakarta: Intermasa.

Suherman, Ade Maman. (2004). Perbandingan Sistem Hukum. Jakarta: Rajagrafindo Persada.

Tumbuan, Fred B. G. (2007). Presentation on Organ of the Perseroan Terbatan According to Law No. 40 Year 2007. Makalah. Disajikan pada Seminar Sehari. "Aspek-aspek Penting Undang-undang No. 40 Tahun 2007 tentang Perseroan Terbatas. Jakarta, 28 November 2007.

Wilamarta, Misahardi. (Tanpa Tahun). Hak Pemegang Saham Minoritas Dalam Rangka Good Corporate Governance, Program Pasca Sarjana, Fakultas Hukum Universitas Indonesia. 